wash with phisophex, and a reduction in cutaneous flora in other parts of the body, from which staphylococci can be shed, could be expected if a soap medicated with hexachlorophane were provided for each nurse to use in her bath, though whether the girls would resent such an intrusion into their cosmetic and social prerogative is another matter. An alternative to the ase of hexachlorophane in any of the forms referred to is thorough rinsing of the hands in $70 \%$ alcohol or in $70 \%$ alcohol containing $0.5 \%$ chlorhexidine before performing any service for an infant; Lowbury and Lilly found this to be "surprisingly effective." It is unlikely that any hand-cleansing routine, however effective against bacteria, will eliminate cross-infection in paediatric wards and nurseries, or indeed anywhere else, unless it is applied in conjunction with other measures designed to control the dissemination and spread of micro-organisms.

$$
\text { REFERENCES }
$$

1 Brit. med. J., 1960, 2, 1792

2 Lowbury, E. J. L., and Lilly, H. A., ibid., 1960, 1, 1445.

\section{Salmonella Carrier}

Q.-A family had a Salmonella typhimurium infection in November. All except the daughter, aged 11 months, responded to chloramphenicol. She still has strongly positive stools, although clinically well. In addition to chloramphenicol she has had colimycin + furoxone (10 days) and framycetin (8 days). After regular control cultures the salmonella has throughout retained its sensitivity to antibiotics. What can be done to clear up the infection and prevent the baby from becoming a chronic carrier?

A.-Forget about it for three months, when it is very likely to be found that the condition has cleared itself. Eventual spontaneous clearance is so much the rule that evidence for the efficacy of any treatment is difficult to obtain. If the questioner is anxious to try something else there is paromomycin ("humatin "), for which claims have been made in this connexion. Like neomycin and framycetin, to which it is closely related, it is very little absorbed when given orally and hence acts only in the bowel. A combination of antibiotic and substitution therapy was apparently successful in the hands of J. S. Doyle $^{1}$ in clearing 9 out of 10 carriers of $S$. typhimurium aged $1 \frac{1}{2}$ to 5 years: they were given oxytetracycline together with an antibiotic-resistant lactobacillus preparation ("enpac"). This work requires confirmation.

\section{REFERENCE}

1 Doyle, J. S., Lancet, 1960, 1, 1073.

\section{Tight Socks and Deformed Toes}

Q. - What part is played by socks and stockings in the causation of deformities of the toes? Many shops now sell only the stretch-nylon type of sock for infants. Should these be advised against, or would it be satisfactory if they were to be used for smaller feet than those for which they are intended?

A.-While it has often been stated that foot deformities are caused by socks which are too tight there is no trustworthy evidence that they do so. I believe the stretch-nylon type of sock would be perfectly suitable for infants. Some people will hold different views, but evidence for or against this is entirely lacking.

\section{Corticosteroids and Tertian Syphilis}

Q.-What is the present position in the treatment of tertian syphilis with corticosteroids?

A.- Corticosteroids appear to be of limited value in the treatment of late syphilis, but much of the evidence is incomplete and conclusions are tentative. They have been used to prevent or diminish the Jarisch-Herxheimer reaction in cases of early and late syphilis. There is sound evidence that the effects of this reaction can be diminished by cortico- steroids in cases of early syphilis; it seems likely that they would atso be effective in cases of late syphilis, but at present the evidence no more than suggests the possibility. These drugs have also been used to prevent reactions in patients known or believed to be sensitized to penicillin, but this might be dangerous because the degree of protection is uncertain. They have been used experimentally for the relief of lightning pains and abdominal crises of tabes dorsalis, but, although some of the patients appeared to benefit, the effects on symptoms so prone to variation and remission were difficult to estimate. Corticosteroids are well established in the suppressive treatment of interstitial keratitis, and there is some evidence to suggest that they may be useful in the treatment of nerve deafness in the late stages of congenital syphilis.

\section{Proguanil and Fertility}

Q.-Is it true that proguanil hydrochloride taken over a long period tends to cause infertility by interfering with ovulation? Does it also aggravate mid-and pre-menstrual pain?

A.- There is no evidence, published or otherwise, indicating that proguanil has any effects on fertility, ovulation, or menstrual pain. Suggestions of the kind mentioned by the questioner have arisen in connexion with the long-term administration of almost all prophylactic malarial drugs, but no sound basis for them has ever been demonstrated. It is perhaps worthy of mention that intensive searches for effective, orally administered means of diminishing fertility have been carried out for many years and those who have conducted these searches have never claimed that proguanil or other antimalarial substance has any effect on fertility.

\section{NOTES AND COMMENTS}

Corrections.-The appreciation of the late Dr. Elliott P. Joslin written by Dr. George Graham (March 10, p. 729) was extracted from Dr. Graham's obituary of Dr. Joslin published in the current issue of Balance, the journal of the British Diabetic Association (not in the Diabetic Journal as we stated).

We very much regret that in our obituary of Dr. $\mathbf{M}$. $\mathbf{K}$. Acheson (March 24, p. 884) we reversed the places of residence of his two sons. Dr. Roy M. Acheson is lecturer in social and preventive medicine at Guy's Hospital Medical School and at the London School of Hygiene and Tropical Medicine. Dr. Ernest Donald Acheson is medical tutor at the Radcliffe Infirmary, Oxford.

\section{Collected Articles from the "British Medical Journal"}

The following books are available through booksellers or from the Publishing Manager, B.M.A. House. Prices, which include postage, are now the same for both inland and overseas.

Drugs in the Treatment of Disease (36s. 9d.).

Refresher Course for General Practitioners, Volume 3 (26s. 9d.). Any Questions?, Volume 3 (8s. 3d.).

All communications with regard to editorial business should be addressed to THE EDITOR, British Medical Journal, B.M.A. HOUSE, TAVISTOCK SOUARE, LONDON W C.1. TELEPHONE: EUSTON 4499. TELEGRAMS: Aitiology, Westcent, London. ORIGINAL ARTICLES AND LETTERS forwarded for publication are understood to be offered to the British Medical Journal alone unless the contrary be stated.

Authors desiring REPRINTS should communicate with the Publishing Manager, B M.A. House, Tavistock Square, W.C.1, on receipt of proofs. Authors overseas should indicate on MSS. if reprints are required, as proofs are not sent abroad.

ADVERTISEMENTS should be addressed to the Advertisement Manager, B.M.A. House, Tavistock Square, London W.C.1 (hours 9 a.m. to
5 p.m. Tritmedads, Westcent. London

MEMBERS' SUBSCRIPTIONS should be sent to the SECRETARY of the Association. TELEPHONE: EUSTON 4499. 'TELERAMS: Medisecra
Westcent.

B.M.A. Scorrish OFFICE: 7 Drumsheugh Gardens, Edinburgh. 